\title{
Corporation Process Development as the Key Issue of Technical and Economic Breakthrough
}

\author{
Maksim Kuznetsov, and Svetlana Kuznetsova \\ Kazan Federal University, Kazan, Russia
}

\begin{abstract}
The article is devoted to issues of technical and economic development and the strategy of the Russian Federation entering the position of process breakthrough. The role of Russian corporations in the national strategic development is investigated. The decisive role of corporations under conditions of high-tech functioning and the resulting complexity of breakdown solutions is substantiated. The attention is drawn to the inconsistency of Russian corporations with the breakthrough strategy requirements put forward by the government as the national idea, due to low innovation potential. A proposal is made on the use of a systemic synergetic approach to solving issues of process development. The process development is placed at the center of issues being solved and is regarded as a critical condition for the organization and implementation of a process breakthrough.
\end{abstract}

\section{Introduction}

The economic history of post-Soviet Russia is a plunge into a funnel of difficulties, uncertainties, deterministic chaos, short-term revivals, attempts to "the catch up with Portugal", "the jump off the hydrocarbon needle", "switch to an innovative development trajectory", "modernize Russia", implement "the Putin's Program", to effect a "process breakthrough", etc.

The government's efforts to change the situation cannot be ignored. However, we don't have to see outstanding or even good results either. The country holds on, but does not understand why the richest country in the world in terms of natural resources is in the seventh ten countries in terms of business activity, in sixth in terms of the quality of life of the population, in the fifth in terms of achievements in the innovation sphere ...

It is impossible not to see local achievements: liquefied gas, gas pipelines to China, the Crimean bridge, stabilization of the military-industrial complex, energy ... But why somewhere is delayed "process breakthrough", "growth in the well-being of the population", achievements in education and science recognized in the world are not noticeable, medicine, etc.

Neither the government, nor corporations, nor scientists give an answer to the main question: is Russia taking the strategically correct process and economic course, adopting the "Western" (mainly American) economic model?

This paper is not intended to discuss the mistakes of the government, corporations, politicians, scientists, who are primarily responsible for the fact that for 30 years the country has not been able to overcome the barrier of $15 \%$ growth in relation to 1990 , while 
China economically has grown more than 15 times during this time. The article proposes to reflect on the strategy of process and economic development of Russia, and to consider the role of corporations in technical and economic development.

\section{Materials and methods}

In order to discuss strategies, process and economic development, it is proposed to consider the problems, mission of corporations, vision of the future, goals and objectives from the standpoint of a system-synergetic approach, system dynamics, analysis of state statistics data.

\section{Results and discussions}

If the data of state statistics for 1990-2019 are taken as a basis for discussion of some traditional products produced, as a rule, by corporations, then they are as follows (please see table). Corporations operating in the field of oil and gas production are the most successful in comparison with those corporations operating in the manufacturing industries. In general, the share of machine building and metalworking has decreased in the gross domestic product over 30 years from $29 \%$ to $18 \%$.

Table 1. Production performance of certain conventional types of products

\begin{tabular}{|c|c|c|c|c|}
\hline Industry & 1990 & 2000 & 2019 & Remarks \\
\hline \multicolumn{5}{|c|}{ Fuel and energy complex } \\
\hline Mineral coal, mm. t. & 395 & 258 & 439 & \\
\hline Crude oil and gas condensate & 518 & 324 & 561 & \\
\hline Natural and casinghead gas, bln. cub. m. & 614 & 584 & 738 & \\
\hline Electrical power generation, bln. kwh & 1082.2 & 877.8 & 1118 & \\
\hline \multicolumn{5}{|c|}{ Metallurgical complex } \\
\hline Cast iron, mm. t. & 59.4 & 44.8 & 51,2 & \\
\hline Steel, mm. t. & 89.6 & 59.2 & 58.6 & \\
\hline Bars & 63.7 & 46.7 & 61.5 & \\
\hline \multicolumn{5}{|c|}{ Chemical industry } \\
\hline Sulphuric acid, mm. t. & 12.8 & 8.3 & 13.4 & \\
\hline Sodium carbonate, $\mathrm{mm}$. $\mathrm{t}$. & 3240 & 2201 & 3383 & \\
\hline Caustic soda, th. t. & 2258 & 1241 & 1289 & \\
\hline Synthetic resin, th. t. & 3258 & 2576 & 8259 & \\
\hline Styrene, th. t. & 446 & 328 & & \\
\hline Ethylene, th. $\mathrm{t}$ & 2318 & 1889 & 2964 & \\
\hline Chemical fibre, th. t. & 673 & 164 & 192 & \\
\hline Synthetic fibre and yarn, th. t. & 317 & 105 & 173 & \\
\hline \multicolumn{5}{|c|}{ Machine-building complex } \\
\hline Diesel and diesel generators, th. pcs. & 23.2 & 4,8 & & $\begin{array}{c}\text { Decline by } 4.5 \\
\text { times }\end{array}$ \\
\hline Turbines, mln. kwh & 12.5 & 2.1 & 2.0 & Decline by 6 times \\
\hline Rolling bearing, mln. Pcs. & 784 & 257 & 43.2 & $\begin{array}{c}\text { Decline by } 18 \\
\text { times }\end{array}$ \\
\hline Overhead crane, th. pcs. & 2943 & 638 & 1823 & $\begin{array}{c}\text { Decline by } 1.5 \\
\text { times }\end{array}$ \\
\hline Tower crane, th. pcs. & 2526 & 36 & 73 & $\begin{array}{c}\text { Decline by } 30 \\
\text { times }\end{array}$ \\
\hline Tractors, th. pcs. & 214 & 19.2 & 6.7 & $\begin{array}{c}\text { Decline by } 35 \\
\text { times }\end{array}$ \\
\hline Wheel tractors, th. pcs. & 96,6 & 6.9 & 6.5 & $\begin{array}{c}\text { Decline by } 14 \\
\text { times }\end{array}$ \\
\hline Caterpillar tractor, th. pcs. & 121.5 & 12.4 & 0.2 & $\begin{array}{c}\text { Decline by } 600 \\
\text { times }\end{array}$ \\
\hline
\end{tabular}


Table 1. Continued

\begin{tabular}{|c|c|c|c|c|}
\hline Harvester thresher., th. pcs. & 65.7 & 5.2 & 4.8 & $\begin{array}{c}\text { Decline by 13 } \\
\text { times }\end{array}$ \\
\hline Metal-cutting machine, th. pcs. & 74.2 & 8.9 & 4.2 & $\begin{array}{c}\text { Decline by } 16 \\
\text { times }\end{array}$ \\
\hline Forging and pressing machines, th. pcs. & 27.3 & 1.2 & 4.5 & Decline by 6 times \\
\hline
\end{tabular}

Resources: Rosstat, 2001-2020.

The production of many types of mechanical engineering products has been reduced tenfold. Russia, in the not-so-distant past, having 15 plants of a full process cycle for the production of tractors and several dozen aggregate factories of a tractor profile, switched to the import of foreign tractors, leaving the residents of Rubtsovsk, Vladimir, Petrozavodsk, Volgograd, Chelyabinsk and other cities without jobs.

The same is with the production of motorcycles, road-building equipment (bulldozers, excavators), metal-cutting machines, automatic metal-working lines, forging and casting equipment, tower cranes with a lifting capacity of 5 tons and more, grain harvesters, agricultural loaders, etc., the production of which reduced tenfold.

The import substitution program was a strategically correct and urgently needed decision. If we were talking about high-tech products, it would still be possible to come up with some kind of excuse, but we are talking about products that have been produced in Russia for a long time and serially and even in large quantities [1].

Managers of modern corporations explain failures in the production of relevant products by the lack of "demand", "analogues", process materials, high precision equipment, high technologies, without which it is impossible to enter world markets, etc. [2]

The Uralmashplant in Sverdlovsk has exported its products (excavators, drilling rigs, rolling mills, crushing equipment, etc.) to more than 100 countries. The Ukhtomsky agricultural machinery plant (Lyubertsy) exported to 40 countries of the world. And there are thousands of them.

The largest corporations of the country included research institutes, factories - technical colleges, problem laboratories, experimental design bureaus, automation and mechanization laboratories, powerful central factory laboratories capable of carrying out complex process and design developments.

By privatizing large state-owned enterprises and splitting them into small enterprises, and then selling them to "effective owners," the state turned them into colossus with feet of clay without scientific infrastructure, effectively killing factory science [3].

Having liquidated sectoral ministries, it left sectoral institutions, sectoral science, which occupied an honorable place in the national innovation system of Russia, to the mercy of fate.

The Leningrad Optical and Mechanical Association (LOMO), with its powerful research infrastructure, was a leader in its industry. Where is it now?

Where is the Likhachev automobile plant (the legendary ZIL) and its plant, the technical college and powerful design organization (SPTU-ZIL), the well-equipped central factory laboratory (TsZL ZIL)?

Such and similar corporations no longer exist. Without factory and industry science, once powerful corporations are unable to create high technologies and move our industry into a knowledge economy and be competitive. They are unable to implement the tightening process and economic regulations of the WTO, they are not able to master new materials and technologies (except for corporations of the military-industrial complex, where this infrastructure has been preserved).

Today, corporations with a powerful laboratory infrastructure are "making politics" and "making history", where the cost of one workplace of a researcher reaches \$ 5 million, and the cost of the laboratories themselves reaches $\$ 1$ billion.

Such corporations rule the world. 
However, among appeals to corporations about the need to raise the level of competitiveness are not enough to realize a process breakthrough. In addition to the tightening requirements for the level of research and development costs (in the USA they are approaching $\$ 500$ billion through the state, in China they exceed $\$ 300$ billion ...), it is necessary to master a high methodological level of implementation of all stages of the life cycle of creating world-class innovations - the choice of the vector of technical and economic development (foresight forecast and vision of the image of the future on the strategic horizon, the development of a mission, goals and objectives ...), it is necessary to find the optimal ratio of self-organization and management in terms of resources and goals, to ensure the harmony of the strategic interests of the state and corporations participating in breakthrough projects, synchronization of their actions in order to obtain not local successes, but synergistic effects ... The trajectory of movement not along isolated quantitative increments, but along the front line of qualitative synergistic effects is the process development in the conditions of a cascade of industrial revolutions of the $21 \mathrm{st}$ century [4].

Attempts to implement such development are being made in the Vologda region, Rostov-on-Don, the Republic of Tatarstan and other regions of the Russian Federation.

In Tatarstan, for example, the online forum discusses the strategy of movement not along a trajectory with local "economic effects" with multi-vector interests of participants in process development, but along a trajectory of coordinated synergistic effects. Possessing powerful clusters of oil production (Tatneft), oil refining (Nizhnekamsk neftekhim, Taneko, Nizhnekamskshina, etc.), the automotive industry (PJSC KamAZ, car assembly plants in Yelabuga), aircraft construction (aircraft and helicopter plant in Kazan), shipbuilding (Zelenodolsk), construction, compressor-building, energy, chemical, etc., the region is facing the same destructive trends as other regions. Self-organization in conditions of a high level of uncertainty, instability, disequilibrium means the choice of such azimuths of development that minimize economic dysfunctions, fully or partially convert them into advantages. On the site of a car plant under construction in Yelabuga, the most successful Special Economic Zone "Alabuga" was created; Technopolis "Khimgrad" was created on the premises of the film production plant; industrial and process parks and business incubators were created on the ground of ineffective enterprises in Naberezhnye Chelny, Bugulma, Leninogorsk, Chistopol. The city of Innopolis was built, a center for digital technologies with a university, which are gaining popularity not only among local students, but also among foreign youth.

The nonlinearity and turbulence of the dynamics of process development in the format of self-organization is overcome by foresight: forecasting, mastering the provisions of economic synergetic.

Achievements in process development are also in other regions of Russia (Moscow, Moscow region, Nizhny Novgorod, Voronezh, Sverdlovsk, Tula, Novosibirsk, etc.). They are similar to those achieved in Tatarstan. However, these rates are not enough to ensure the growth of the well-being of the country's population, its security and the elimination of the gap in comparison with the leaders of process development [5].

The real incomes of the country's population have been declining for six years. The transition from a planned to a spontaneous economy in 30 years did not give the results that were expected. On the one hand, there was no deficit, then other problems appeared: unemployment, financial debts of $50 \%$ of the country's population, low process efficiency of production systems [6].

The hopes were pinned on "effective owners", privatization, development institutions, property inequality, the replacement of process planning with marketing, free markets, entrepreneurship, etc. But hopes did not come true [7]. 
Ahead are process wars for survival on Earth, for the minerals of the Moon, Mars, etc.; mastering high technologies in the field of genetic engineering, mechatronics, atomic and laser microscopy, wave genetics, polarized photons, mutagenesis and everything that is the main directions of the sixth and seventh process modes. Russia lingered in the fourth process order, it is dangerous [8].

To break into the sixth and seventh process structures, it is necessary to radically reorganize the training of highly qualified specialists, the main goal is to consider the creation of scientific schools headed by scientists, problem laboratories in corporations and universities. Provide them with targeted programs, equip them with research equipment of the highest level. Without government programs, factory and industrial science and the Russian innovation system, it will not be possible to break through into the 6th and 7 th process modes.

\section{Conclusions}

1. The role of Russian corporations in the breakthrough strategy of technical and economic development is not at the level that is capable of providing a process breakthrough.

2. It is required to adjust the paradigm level in goal-setting, methodology, organization, management of process development, research and development, elimination of the consequences of destructive "transformations" in corporations aimed at destroying their scientific and process potential and, above all, scientific infrastructure.

3. Strategies of "process breakthrough" and "import substitution" are threatened by the same fate as other correct strategies, but not provided with concrete measures for their implementation.

4. The revival of the corporate sector in the Russian Federation in the format of an innovation-transforming body that has the necessary and sufficient means of process breakthrough is not an optional, but a critical condition for the country's survival in the context of a permanent process revolution of the 21 st century, when high technologies will determine the face of planet Earth.

\section{References}

1. N.V. Andreeva, A.S. Gromova, Makasheva, Economy of Region, 4, 69 (2015)

2. V.L. Baburin, K.V. Rostislav, Journal of New Economy, 3, 5 (2019)

3. A.I. Tatarkin, V.1. Bersenev, Economy of Region, 12(2), 325 (2016)

4. B.L. Kuznetsov, The theory of synergic development of economic systems, 183 (2010)

5. V.S. Bochko, Economy of Region, 12(2), 343 (2016)

6. O.C. Sukharev, Economy of Region, 12(2), 359 (2016)

7. S.D. Bodrunov, Ural federal University J., 20(1), 5 (2019)

8. M.N. Lukyanova, The Eurasian Scientific J., 4 (2018) 